\title{
THE EFFECT OF PROBLEM BASED LEARNING MODEL ASSISTED ANIMATION ON HEAT AND TEMPERATURE MATTER
}

\author{
Dwira Nababan dan Rahmatsyah \\ Physic Department State University of Medan \\ Dwirapitasarinababan@yahoo.com
}

\begin{abstract}
The introduction of material authentically accompanied with active learning, that is the learning process very effective to increase student learning outcomes. The aim of this research to determine the effect of problem based learning model assisted animation to increase student learning outcomes. This research is a quasi-experimental. The instruments that used in this research was 10 essay test that have been pass validity test. The population on this research were all students of class X SMA Negeri 1 Berastagi while the sample that taken was two classes, that is $\mathrm{X}$ MIPA 7 and X MIPA 8 where X MIPA 8 as the experimental class and the amount of students was 32 students taught with problem based learning model and X MIPA 7 as control class and the amount of students was 30, was taught with conventional learning model. There are two kinds of research data that is in form of learning outcomes and observation of student activity. The data on learning outcomes was begins with normality and homogeneity test. The average results of students learning outcomes on experiment class was 87.53 while the control class was 85.14 . The activity data are presented on percentage of individual activity classically. The activity for classes taught with PBL model was reach 82.01, while the class taught by conventional learning model was 60.26 . There was increasing of students activity with problem based learning model as much as $26.52 \%$. There was effect of PBL assisted animation to increase student learning outcomes on topic Heat and temperature at grade $\mathrm{X}$-science in SMAN 1 Berastagi, the average was 2.77 $>1.67$, so that $\mathrm{H}_{0}$ is refused and $\mathrm{H}_{\mathrm{a}}$ is accepted .
\end{abstract}

Keyword: problem based learning, activity, learning outcomes. 


\section{INTRODUCTION}

A great education is an education that can lift up the dignity and value of a state. Education established automatically can make a nation speak in the international area. Learning activity is one of the most vital components in determining the quality of education. Learning activities performed by two actors, are teachers and students. The behavior of the teachers is teaching and students are learning behavior. Teaching behavior and learning behavior is related to the subject matter. Learning is essentially a process of interaction between teachers and students, either direct interaction such as face-to-face activities and indirectly, by using a variety of instructional media.

Teachers as classroom manager should be able to manage the classroom as a learning environment that needs to be organized. As a manager, a teacher is responsible for maintaining the physical environment of the class to always fun to learn and directing or guiding the processes of intellectual and social in its class. Thus the teacher not only allows students to learn, but also develop the ability to work and learn effectively from among students. The teacher can actually improve adequate results in the learning process, where teachers as educators are able to leverage the model and the right media in learning. In teaching, the teacher always requires students to learn, teachers also require students to solve problems, but rarely teach how students should solve the problem (Arends, 2009). On the other hand, suggests that the curriculum Problem Based Leaning (PBL) helped to boost the development of lifelong learning skills in a mindset that is open, reflective, critical, and active learning.

Based on data reported by the Department of Education of North Sumatra, Friday (25/5), students in senior high school / MA that pass the UN amounted to 119,945 people $(99.88 \%)$ of the 120,090 participants. While the students who pass the exam is 72,410 people $(99.87 \%)$ of 72,504 participants. For the IPA program, from 62,331 participants from the UN SMA / MA in North Sumatra, which pass as many as 62, 257 people or 99.88 percent. As for the national level graduation rate reached 99.70 percent of the 628,495 participants. Especially for high school, there are eight regencies / cities in North Sumatra with a 100 percent graduation. The eighth area of each Sibolga, as well as Pakpak Bharat, West Nias, Dairi, Mandailing Natal, North Padang Lawas, Humbang Hasundutan and Nias.For the MA level, 100 percent graduation occurred in 24 of 33 districts / cities in North Sumatra. Nine districts were still some students do not pass the exam include Medan and Deli Serdang, Langkat, Labuhan Batu, Karo, South Labuhan Batu, shavings, South Tapanuli, Asahan and North Padang Lawas.

Problem based learning $(\mathrm{PBL})$ is an instructional approach that provides learners with opportunities to identify solutions to structure, real-world problems. Problem-based learning (PBL) is an instructional approach that enables 
learners to conduct research, integrate theory and practice, and apply knowledge and skills in order to develop a solution to a defined problem (Savery, 2006). According to Barrows (2002), the key components of PBL are , unresolved, ill-structured problems that will generate multiple thoughts about the cause and solution, a studentcentered approach in which students determine what they need to learn , teachers serve as facilitators and tutors, and problems are authentic and reflect professional practice. Barrows (1996) also suggests that learning in a PBL environment should be integrated from a wide range of disciplines or subjects such that students study and integrate information from diverse disciplines that might relate to understanding and solving a particular problem. In short, PBL is an approach to learning in which students work together to find solutions to complex problems (Ferreira \& Trudel, 2012).

\section{THE OBJECTIVES OF RESEARCH}

1.The student's learning outcomes with Problem based learning model assisted animation on topic heat and temperature at grade $\mathrm{X}$-Science in SMA N 1 Berastagi A.Y .2015/2016

2.The student's activity with conventional model on topic heat and temperature at class X SMA N 1 Berastagi A.Y.2015/2016

3. The student's activity with Problem based learning model assisted animation on topic heat and temperature at grade $\mathrm{X}$-Science in SMA N 1 Berastagi A.Y .2015/2016

\section{METHODE OF RESEARCH}

Population in this research is students at grade $\mathrm{X}$ SMAN 1 Berastagi Academic year 2015/2016 which is consist of 12 class where 8 science class and 4 non science. In this research, the sample is taken randomly(random sampling) consists of 2 class, that is $X$ science 7 as experiment class and $\mathrm{X}$ science 8 as control class.

This type of research that used in this research is quasiexperimental. Quasi objectives is to obtain information by providing a treatment to a group of students using learning model problem based learning (PBL) assisted animation on topic Heat and Temperature. This research involved two classes are treated differently. One class used as an experimental class and other classes used as the control class.

\section{RESULT AND DISCUSSION}

The data of research result include result of pre-test ,post-test and $\mathrm{N}$-gain on PBL model that shown on Figure 1.

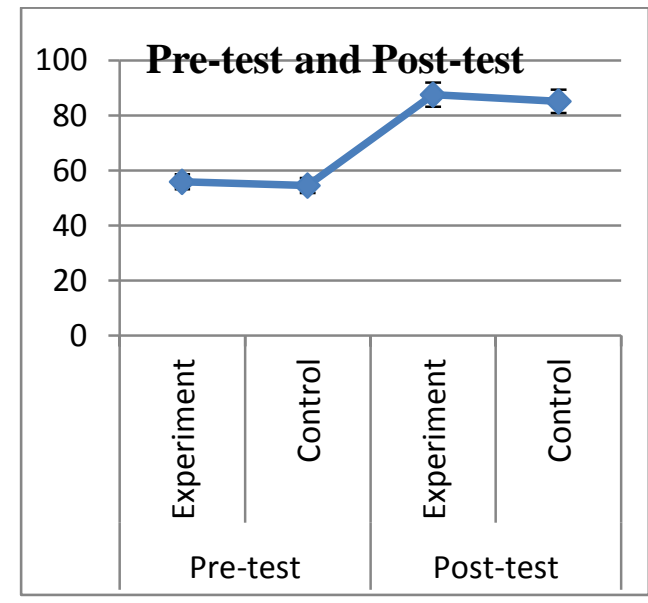

Figure 1. The average of pre-test and post-test 
The normality test results obtained by using the formula Liliefors data. The post-test data from both of class are normally distributed.

Homogeneity test is used to determine whether the sample class derived from homogeneous population or not. The value of $F_{\text {count }}<F_{\text {table }}$,it is means that the sample that used in this research is homogenous or can represent the entire population.

The data was normal and homogenous, so hypothesis must be tested. In this research we use differential test (t-test). Find the initial ability of students from both of class used test two tail. As for knowing there is the effect of problem based learning assisted animation to increase students learning outcomes or not, it is used ttest one tail .

The pre-test data from both of class $t_{\text {count }}<t_{\text {table }}=0.99<2.00$, so that $\mathrm{H}_{0}$ is accepted and $\mathrm{H}_{\mathrm{a}}$ is rejected . It can be concluded that there is no different about initial knowledge between both of class before given the treatment (initial ability is same) in SMAN 1 Berastagi.

The result that showed there is no different about initial knowledge from both of class and there is effect of PBL assisted animation to increase student learning outcomes in topic Heat and temperature at grade $\mathrm{X}$-science in SMAN 1 Berastagi.

The aim of observation was to observe students activity during learning process. The observation of students activity have been done during learning process by observer who has assessment's sheet of students activity . Based on the data, the experiment class has mean 82.01 and for control class, it has 60.26. So, it can be conclude,that there was increasing of students activity with problem based learning model as much as $26.52 \%$.

\section{Discussion}

The results showed that there is effect of Problem Based Learning model assisted animation to increase student learning outcomes in topic Heat and temperature at grade $X$-science in SMAN 1 Berastagi .It's can be seen from difference of learning outcomes and observations of activity between experimental class and control class. The result of research using problem based learning model can increase students learning outcomes and student activity. The result of students learning outcomes in experimental class that given treatment with applying problem based learning model was different with control class that taught with conventional learning models that have previously been known has the same initial ability was 55.87 for the experimental class and 54.57 for the control class where criteria test Ho was accepted if $-t_{1-1 / 2 \alpha}<t<t_{1-1 / 2 \alpha} \quad(-2,00<0.99$ $<2.00)$. The value of $t_{\text {count }}$ was layed on $\mathrm{H}_{\mathrm{o}}$ area so $\mathrm{H}_{\mathrm{o}}$ was accepted that is the initial ability from experimental class and control class were same on Heat and temperature topic (there is no significant effect).

\section{CONCLUSION}


1. The results of student learning outcomes using Problem Based Learning (PBL) was 87.53

2. The results of student learning outcomes using conventional model was 85.14

3. The value from students activity using conventional learning model was 60.26

4.The value from student activity using Problem Based Learning (PBL) was 82.01.

\section{REFFERENCES}

Arends, R.I. 2009. Learning to Teach (Belajar untuk Mengajar). Yogyakarta: Pustaka Pelajar

Barrows, H.S.1996. Problem-based learning in medicine and beyond: A brief overview. New Directions for teaching and Learning, 68(Winter), 2-12.

Barrows, H. S. 2002. Is it truly possible to have such a thing as $d P B L$ ? Distance Education, 23(1), 119-122.

Ferreira, M.M. \& Trudel, A.R. 2012. The impact of problem based learning (PBL) on student Attitudes towards science, problemsolvingskills, and sense of community in the Classroom.Journal of Classroom Interaction, 47(1), 23-30.

Savery, J. R. 2006. Overview of problem-based learning: Definitions and distinctions.

Interdisciplinary Journal of Problem-based Learning, 1(1), 9-20. 